INTERGOVERNMENTAL FORUM on Mining, Minerals, Metals and

Sustainable Development

\title{
CASESTUDY
}

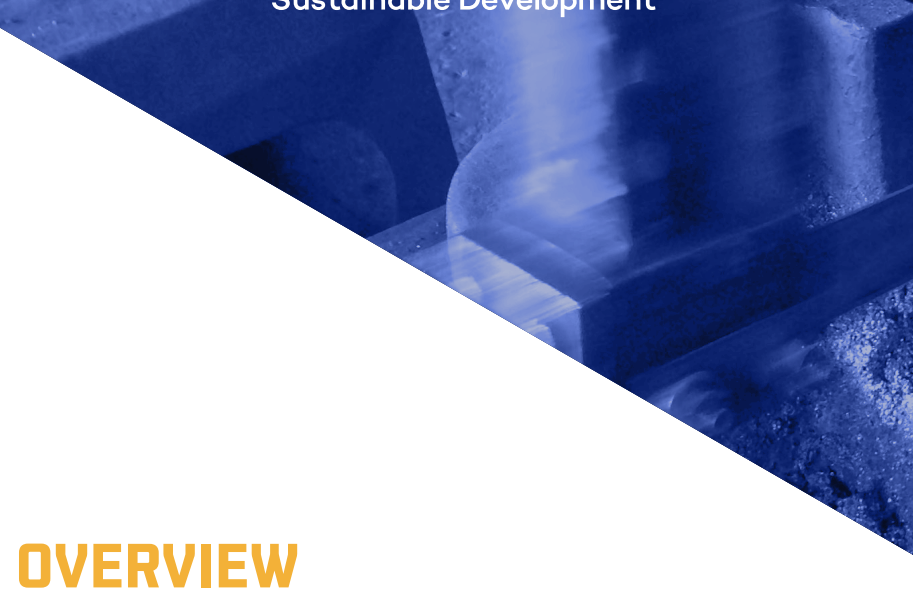

\section{LEVEL OF OPERATION:}

National

\section{GOVERNMENT ROLE:}

GQVERNMENT-LEDINVESTMENTS TN THE OIL AND GAS SEGTORS

Regulator; operator

\section{LINK TO POLICY ADOPTED:}

see Nigerian National Petroleum Corporation

\section{KEY COMMODITIES:}

Natural gas, petroleum, $\operatorname{tin}^{1}$

\section{TOTAL NATURAL RESOURCE RENTS [AS \% OF GDP] [2015]:}

4.7 per cent ${ }^{2}$

\section{NATIONAL EXTRACTIVES COMPANY:}

Nigerian National Petroleum Corporation

UNDP HUMAN DEVELOPMENT INDEX VALUE [2016]:

0.527 (Global Rank 152) ${ }^{3}$
Despite the presence of favourable factors for a successful downstream industry-namely, large reserves of crude oil (the 10th largest in the world), domestic demand for refined petroleum that exceeds current production and historical government efforts to encourage a domestic industry-Nigeria has rarely been able to meet its domestic demand and become a net exporter. Less than 1 per cent of national GDP comes from the downstream oil sector.

Political interference in the management of the refineries has created obstacles for the sector and paved the way for persistent under-capacity utilization. Voices for full privatization of the downstream sector have risen on the grounds that "ordinary citizens are not the main beneficiaries of the Nigerian National Petroleum Corporation (NNPC)'s unreliable refineries." ${ }^{4}$ Nigeria's downstream policy to date has resulted more in draining government coffers than in promoting value addition and local benefits.

\footnotetext{
Central Intelligence Agency (CIA). (2017). The world factbook. Washington, DC: CIA. Retrieved from https://www.cia.gov/library/publications/theworld-factbook/fields/2111.html

2 World Bank Group. (2017). Total natural resource rents (\% of GDP). Washington, DC. Retrieved from https://data.worldbank.org/indicator/NY.GDP.TOTL.RT.ZS ${ }^{3}$ United Nations Development Programme. (2016). Human Development Reports: Nigeria. Geneva, Switzerland. Retrieved from http://hdr.undp.org/en/ countries/profiles/NGA

4 Sayne, A. (2015, August). Inside NNPC oil sales: A case for reform in Nigeria. Natural Resource Governance Institute. Retrieved from https://resourcegovernance.org/analysis-tools/publications/inside-nnpc-oil-sales-case-reform-nigeria
} 


\section{NIGERIA'S DREAM OF BECOMING A NET EXPORTER OF REFINED PRODUCTS}

Nigerian oil has a high export value given that it is less corrosive for refinery infrastructure and easier to refine into high-value products such as gasoline or jet fuel compared to other types of crude. However, only a decade after discovering its first oil, Shell and BP built the first refinery in 1965 in Port Harcourt
In 1975 and 1976, the government awarded the construction of two additional refineries to international consortia: the Warri Refinery project with a production capacity of $100,000 \mathrm{~b} / \mathrm{d}^{7}$ for producing motor oil for Nigerian consumption, and the Kaduna Refinery project with a production capacity of $50,000 \mathrm{~b} / \mathrm{d}$ for regular fuels and 50,000 $\mathrm{b} / \mathrm{d}$ for lubricating oils, waxes and asphalt. These two refineries were government-owned, and in 1978 the Port Harcourt Refinery was also nationalized, with the government acquiring the remaining 40 per cent of equity from Shell and BP. In 1985, the NNPC commissioned a second refinery at Port Harcourt with a capacity of $150,000 \mathrm{~b} / \mathrm{d}$. The intention was to turn Nigeria into a net exporter of refined petroleum over the following two years. ${ }^{8}$

with an initial capacity of 38,000 barrels per day (b/d). The intent was to satisfy domestic gasoline demand for the transportation market. $^{5}$

In 1969, the government passed the National Petroleum Act, ${ }^{6}$ which vests ownership of all petroleum resources of Nigeria in the state and stipulates a domestic obligation for international oil companies, requiring upstream producers to "subsidize" the local refineries by selling around 8 per cent of their crude oil production at a price of about USD 1.80/barrel, which was about 5 per cent of world market price up until around 1985.

Throughout the 1970s, the government progressively increased its participation in the equity of all oil international oil companies' operations in Nigeria until it reached 60 per cent in 1978. The Nigerian National Petroleum Corporation (NNPC) was established to control the government's share of the international oil operations.
By the end of 1991, however, decreasing production at the Warri and Kaduna refineries combined with increasing domestic demand for refined petroleum stopped exports from the new Port Harcourt refinery. Since that time, Nigerian has been a net importer of refined petroleum products. In 2015, petroleum refined domestically made up little more than 5 per cent of the petroleum products consumed in the country.

This may change, as in 2015 the government signed a memorandum of understanding with Epic Refinery Group for the construction of a 100,000 b/d refinery in Delta Bayelsa State ${ }^{10}$ and the African magnate Aliko Dangote has commissioned a 650,000 b/d refinery which would more than double the country's current refining capacity. ${ }^{11}$ With these two latest refinery plans, Nigeria aims again at becoming a net exporter with sufficient fuel capacity to supply its domestic market.

\footnotetext{
5 Ibanga, I. (n.d.). The economics of privatizing and deregulating the Nigerian downstream oil sector. Valore International. Retrieved from http://www.florin.com/valore/ifiokibanga.html

${ }^{6}$ Laws of Nigeria. National Petroleum Act of 1969. Retrieved from http://lawsofnigeria.placng.org/laws/P10.pdf

Ogedegbe, A. (2009, June 11). The Nigerian petroleum refineries: History, problems and possible solutions. The Nigerian Academy of Engineering

8 lbid.

9 Ibid.

10 Bivbere, G. (2016, January 12). Firm signs agreement for 100,000 bpd private refinery. Vanguard. Retrieved from http://www.vanguardngr. com/2016/01/firm-signs-agreement-for-100000bpd-private-refinery

11 Onyekakeyah, L. (2016, July 12). The Dangote Lekki refinery. The Guardian. Retrieved from http://guardian.ng/opinion/the-dangote-lekki-refinery/
} 


\section{MISMANAGEMENT QF THE STATE-DWNED REFINERY BUSINESS}

The troubled state of Nigeria's four existing stateowned refineries reflects the management practices of the NNPC, including the following factors:

- The NNPC's opaque handling of the money collected from crude sales has weakened the financial health and credibility of the NNPC. The government allocates about 445,000 barrels to the NNPC for the domestic refineries daily, but since the four Nigerian refineries can only physically process around 100,000 barrels per day, the reality is that the NNPC reroutes most of this crude to the export market or uses it for petroleum for product swaps. The payments from these transactions enter the NNPC accounts with no clear accounting rules and transparency. The NNPC has exerted discretionary withholding on these payments to finance subsidies and cash calls from operations and has been sending less and of less of this money to the Federal government over time.

- Inadequate funding and long decision-making processes have delayed important investments in maintenance and aging infrastructure.

- The lack of trained, experienced staff has led to poor monitoring of the refinery systems. ${ }^{12}$

- Maintenance has been neglected due to shortages of spare parts. The combination of these issues has led to frequent shutdowns of units or entire refineries. Fires have occurred frequently at NNPC-operated refineries.
Figure 1. Pipeline vandalism incidents as per NNPC reports



Source: Wapner, 201716
- Disruption of distribution networks has resulted in losses. 40 per cent is lost due to sabotage, theft and equipment failure..$^{13}$ In 2011, for instance, the NNPC reported "Pipeline vandalism increased by 224 per cent over the previous year [see Figure 1]. A total of 2,787 line breaks were reported on NNPC pipelines out of which 2,768 were as a result of vandalism, while 19 cases were due to system deterioration resulting in a loss of $157.81 \mathrm{mt}$ of petroleum products worth about N12.53 billion (roughly USD 77 million in 2011). There were 25 fire incidents during the year under review." ${ }^{14}$ This vandalism is often associated with the smuggling of petroleum products to neighbouring countries (The World Bank notes that the amount of petroleum smuggled is routinely close to 10 per cent of operating capacity). ${ }^{15}$ Smuggling became a major source of corruption. The smuggling was largely encouraged by the fuel subsidy: petroleum products were sold in neighbouring markets at prices that were as much as 15 times higher.

\footnotetext{
12 Ogedegbe (2009), Id. note 7.

${ }^{13}$ Interview with Nigeria expert, March 2017.

14 Nigerian National Petroleum Corporation. (2011). 2011 draft annual statistics bulletin. Corporate Planning and Strategy Division. Retrieved from http://www.nnpcgroup.com/Portals/O/Monthly\%2OPerformance/2011\%20ASB\%201st\%20edition.pdf.

15 Kahn, S. (1994). Nigeria: The political economy of oil. Oxford Press, 1994.

${ }_{16}$ Wapner, A. (2017, March). Downstream beneficiation case study: Nigeria. Columbia Center on Sustainable Investment Retrieved from http://ccsi. columbia.edu/files/2013/10/Nigeria-Case-Study-May-2017 CCSI-Final-2.pdf
} 
All of these problems have led Nigeria's refineries to produce significantly less than their nameplate capacity (see Figure 2) and costs have soared despite a decline in output which has led to the NNPC to accumulate over USD 1 billion in arrears. ${ }^{17}$

\section{Figure 2. Refining capacity utilization, 2006-2015}

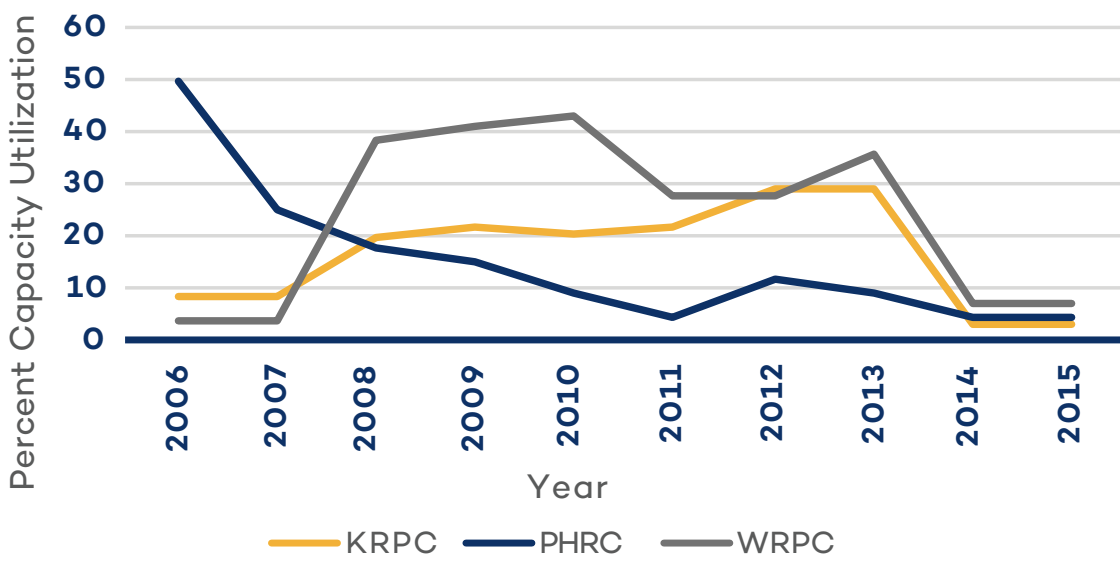

Source: Wapner, $2017^{18}$

\section{KEY LESSONS}

- There are risks to downstream efforts; a government-led investment program to move downstream can drain public resources if unsuccessfully managed;

- If a national company is set to be a commercial operator of the downstream sector, it should operate under a rigorous governance framework isolated from political interference and endowed with sharp technical skills;

- Policy coherence is of utmost importance. The fuel subsidies at the pump, for example, squeezed the refinery sector from making profits and becoming self-sustainable, as it had to pay the unsubsidized rates for crude petroleum.
[I IGF

\section{FOR MORE INFORMATION CONTACT}

Secretariat@IGFMining.org

1100-220 Laurier Avenue W.

Ottawa, Ontario

K1P $5 Z 9$ Canada

IGFMining.org

y @IGFMining f @IGFMining

Written by Perrine Toledano and Nicolas Maennling

Adapted from Downstream Beneficiation Case Study: Nigeria, Columbia Center on Sustainable Investment Retrieved from ccsi. columbia.edu/files/2013/10/Nigeria-Case-Study-May-2017 $\underline{\text { CCSI-Final-2.pdf }}$

Secretariat hosted by:

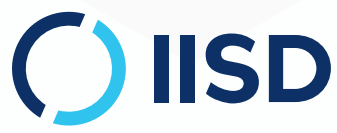

Secretariat funded by:

Canadằ 